Relations industrielles

Industrial Relations

\title{
Michael P. JACKSON : Industrial Relations - A Textbook. 3rd ed., London, Croom Helm, 1985, 294 pp., ISBN 0-7099-1474-1
}

\section{Anthony Giles}

Volume 42, numéro 3, 1987

URI : https://id.erudit.org/iderudit/050355ar

DOI : https://doi.org/10.7202/050355ar

Aller au sommaire du numéro

Éditeur(s)

Département des relations industrielles de l'Université Laval

ISSN

0034-379X (imprimé)

1703-8138 (numérique)

Découvrir la revue

Citer ce compte rendu

Giles, A. (1987). Compte rendu de [Michael P. JACKSON : Industrial Relations - $A$ Textbook. 3rd ed., London, Croom Helm, 1985, 294 pp., ISBN 0-7099-1474-1]. Relations industrielles / Industrial Relations, 42(3), 667-669.

https://doi.org/10.7202/050355ar

Tous droits réservés @ C Département des relations industrielles de l'Université Laval, 1987
Ce document est protégé par la loi sur le droit d'auteur. L’utilisation des services d'Érudit (y compris la reproduction) est assujettie à sa politique d'utilisation que vous pouvez consulter en ligne.

https://apropos.erudit.org/fr/usagers/politique-dutilisation/ 
It appears quite clear from the contributions included in the book, that both in Western as well in Eastern Europe so far lacking the socio-economic forces able and willing to promote initiatives in the field of the social organization of work consistently and strongly enough. Norway and S Sweden are exceptions. But even there, some difficulties are apparent. For example, in Sweden most of the innovative projects come from the management side and this diminished their public appeal. Trade unions remain lukewarm all around Europe. The governmental bureaucracies, being influenced mostly by lawyers and politicians, show very limited understanding. The fear of unemployment contributes to the passivity of the labour force regarding internal labour market innovations.

Only in Yugoslavia is the whole work system supposed to be socially innovative, but in the reality it does not necessarily function this way due to a variety of reasons: one party rule, economic difficulties, organizational weakness, rivalries between various powerful groups. The new ideas promoted in the Soviet bloc by $\mathrm{M}$. Gorbachev should in the long run make much more room for the democratization of the workplace. But, obviously, they are not easy to implement as long as in each socialist country there are enough powerful people to tenaciously defend their privileges.

It is difficult to imagine real progress in European quality of working life without the establishment in each country of a public lobby committed to promote the cause. Mass media in general are positively oriented to innovative projects but they do not usually follow up the events. Academics are more and more in favour and they follow in this respect the progressive trends in the university communities. Modern management training strongly emphasizes the capacity of the manager as a democratic leader.

It is an interesting question if and to what extent the quality of working life movement may become an autonomous factor free from any particular political determination, able to unite the ideologically diversified groups of people who manifest a devise to enrich the sociomoral values of collective work. The principle of teamwork becomes a vital part of the modern civilization, and the economic recovery of Europe depends much, among other things, on the revalorization of this principle. It is quite obvious that the economic success of Japan originates to a considerable degree exactly from this very sort of work culture, based on the cultivation of a co-operative approach. The traditions of European civilization need to be revived in order to make evident progress in cultural unification. Now there is more reason than ever before to see a better chance for Europe. The socio-moral upgrading of collective work in complex organizations is a joint task of a particular attractiveness for several European countries.

It was a very useful to bring together several European experts to promote jointly a discourse on the new forms of work organization. This has already led to more collective projects that are being implemented accross borders.

Alexander J. MATEJKO

University of Alberta

Industrial Relations - A Textbook, by Michael P. Jackson, third edition, London, Croom Helm, 1985, 294 pp., ISBN 0-7099-1474-1

This British textbook is designed to introduce students to the field of industrial relations. Because the empirical contents of the book are presented in conjunction with a number of broad conceptual and theoretical issues and debates, and because the analysis draws on the ex- 
perience of a number of countries other than Britain, the book is better seen as a British introduction to industrial relations than as an introduction to British industrial relations.

In Chapter 1 Jackson reviews systems theory, the social action approach to industrial relations, and the three frames of reference commonly used to interpret industrial relations (unitarism, pluralism and marxism). Chapters 2 and 3 survey trade unions, paying particular attention to union growth and development, aims and objectives, and internal government. The focus of Chapter 4 is on the industrial enterprise, the management function, and employers associations. Chapter 5 introduces the general topic of collective bargaining (its nature and development in Britain and elsewhere, bargaining structures, the social and economic impact of bargaining, and so on), while Chapter 6 examines local and productivity bargaining in more detail. Chapters 7 and 8 discuss industrial conflict and strikes respectively. In Chapter 9 the role of the state is examined. And the presentation is rounded off with a brief conclusion in Chapter 10. On the whole the book is clearly written and well organized.

Several features of Jackson's introductory treatment of industrial relations deserve praise, particularly when compared to most North American introductory texts. In the eyes of this beholder, the book's strongest dimension is its inclusion of - indeed, focus on - theoretical, methodological and ideological debates. From the Preface to the Conclusion, virtually every topic is treated in reference to competing analytical perspectives and explanatory systems. While this emphasis occasionally overshadows the factual material needed by beginning students (as in Chapter 4, for example), the overall balance is satisfying.

A second strength of the book is its use of international comparisons. Although the principal concern is with Britain, nearly every chapter makes use of comparative evidence as a means of illuminating phenomena which are intrinsic to industrial relations everywhere, highlighting those features which vary between nations, and (usually) suggesting what accounts for these variations. In most texts, such comparative material is either forsaken in favour of greater depth of coverage of the author's own country, or is included almost as an afterthought. While one might question the handling of the comparative material in some cases (such as the needlessly detailed excursion into the AFL-CIO in Chapter 2), the general method is more interesting than most introductory texts.

A third strength of the book is its sociological perspective (Jackson being the head of the Department of Sociology at the University of Stirling). It is refreshing to see the subject of industrial relations introduced through the prism of sociology, with its concern for social structure, power relationships, and collective institutions, rather than through the prism of economics which, it must be said, has never truly come to grips with social relations within organizations, or with collective values more generally.

That said, the book is not without its weaknesses. Indeed, the book's strengths are offset in part by a failure to make the best use of the approach adopted.

Although Jackson's use of theory shows that an introductory textbook need not obey Jack Webb's admonition to 'Please just stick to the facts', there is an exasperating tendency for discussions to end on an inconclusive note. While this might have the virtue of letting the reader arrive at her or his own conclusion, it presumes that introductory students are capable of so doing. Furthermore, the attempt to be even-handed tends to smother the sparks of controversy which make such debates worthwhile.

Jackson's handling of the theoretical issues in Chapter 1 is awkward. In particular, the introductory student might be confused by the treatment of the different frames of reference on industrial relations as an alternative to systems theory or the social action approach. In fact, 
the three frames of reference cut across the latter (and other theories as well). Moreover, the supposed novelty of improving on Dunlop's early formulation by applying' open systems theory', will sound a little odd to Canadian ears (and to one pair at the University of Ottawa in particular).

Jackson's particular brand of sociology is also open to criticism. Indeed, the sociology in question is quite traditional - old-fashioned even - and, when combined with his preference for an institutional approach to industrial relations, means that the book makes little use of much of the exciting contemporary British literature on the subject. More broadly, this new edition of the book makes surprisingly little use of studies published since the last edition, and is on the whole oriented to the classics: the Webbs' analysis of the trade unions: Michels on organizational democracy; Berle and Means, Burnham, et al on the industrial enterprise; and so on.

To summarize, then, Jackson's textbook is not entirely satisfactory, but its strengths make it a useful book through which to introduce students to the analytical and substantive controversies which make industrial relations such a provocative subject.

Antony GILES

University of New Brunswick

SOCIÉTÉ INTERNATIONALE DE DROIT DU TRAVALL ET DE LA SECURITE SOCIALE INTERNATIONAL SOCIETY FOR LABOUR LAW AND SOCIAL SECURITY

XII' ${ }^{\oplus}$ CONGRES MONDIAL
$X I I^{\text {th }}$ WORLD CONGRESS

Madrid

20-23 septembre 1988 - 20-23 September 1988

SUJET

1. Sanctions pour violation ou non-application des normes du travail

\section{Les inventions d'employé}

3. Les fonds de pension volontaire et leurs rapports avec les systèmes obligatoires de sécurité sociale

\section{RENSEIGNEMENTS - INFORMATION}

$M$. le professeur Pierre Verge

Faculté de droit

Université Laval

Sainte-Foy, Québec

G1K 7 P4
ITEMS

\section{Sanctions in case of violation or non-compliance with labour standards}

\section{Employees' inventions}

3. Voluntary Pension Funds and Public Social Security Programmes 